\title{
The Rhetoric of Political Conservatism in the Post-Reagan Era
}

\author{
Terri B. Davis \\ Lamar University, Beaumont, TX, USA \\ Email:Terri.Davis@lamar.edu
}

Received 15 December 2015; accepted 5 April 2016; published 8 April 2016

Copyright (C) 2016 by author and Scientific Research Publishing Inc.

This work is licensed under the Creative Commons Attribution International License (CC BY). http://creativecommons.org/licenses/by/4.0/

(C) (i) Open Access

\begin{abstract}
Conservative political thought in the United States has historically been rooted in a compact federalist interpretation of American constitutionalism. This article discusses how the rhetoric of former President Ronald Reagan significantly impact conservative thought and American political discourse in the late twentieth and early twenty-first centuries. Reagan rhetorically constructed the national government as an instrument to effect moral and social reform while viewing state and local governments as the harbingers of a nationalized set of Christian values and morals. His rhetoric fused states' rights with notions of moral progress and human obligation to satisfy three specific political goals: promulgating a states' rights theory of government; increasing the United States' position in international trade; and, nationalizing Christian values and morals. The article traces the history of conservative American constitutional thought from the founding through Reagan's presidency and concludes with a discussion of the ways in which Reagan's rhetoric continues to impact political discourse in the twenty-first century.
\end{abstract}

\section{Keywords}

Political Rhetoric, Constitutional History, Political Theory

\section{Introduction}

The $21^{\text {st }}$ century opened with a conspicuous theme present in American political discourse. Discussions of "Christian morality" resonated through the halls of a Congress that since 1994 had held a Republican majority for the first time in forty years; former President George W. Bush promised to work to restore morality and ethics to classrooms, government, and community life; popular radio talk shows blared out warnings of the "corrupt Clintons", "femi-Nazi" women liberationists, and the family as victims of an immoral, drug-infested society. Once bound by an intensely shared desire to eradicate global communism, political conservatives after the fall of 
the Berlin Wall directed their focus squarely on the state as an instrument to effect moral and cultural reform (Diamond, 1995).

Reform, particularly the notion of using the state as an instrument of reform, appears antithetical to the ideological tenets of traditional conservatism. Traditional conservatives eschew changes in societal, cultural, and political institutions, and the history of political conservativism in the United States is replete with examples of attempts to limit the powers of the national government. A theme consistently held by political conservatives since the Anti-Federalists is that the national government should be significantly limited in areas other than military defense, and that remaining necessary government functions should be reserved to the states. Contrary to this theme, contemporary conservativism seeks to significantly increase the powers of the national government specifically in ways that enable the government to be used as an instrument to define and enforce a nationalized set of religious, cultural, and social mores. Conservativism continues to advocate a "return" to states' rights; however, it simultaneously seeks to ensure that state and local majorities will ascribe to a nationalized set of morals and beliefs that will guide the majoritarian policies produced at the state and local levels.

President Ronald Reagan provided the theoretical and rhetorical base from which to pursue both states' rights and a nationalist agenda. Reagan rhetorically fused compact federalist constitutional theory with notions of moral progress and human obligation to produce a $21^{\text {st }}$ century conservativism that combines 1 ) the traditional conservative interest in promulgating a states' rights theory of government; 2 ) the economic conservative interest in increasing the United States' position in international trade; and, 3) the religious conservative interest in nationalizing Christian values and morals. Reagan's fusion of these three interests was successfully achieved by focusing his rhetorical and political skills on education policy—a policy area that would allow for the satisfaction of these interests simultaneously and without apparent contradiction.

\section{Compact Federalist Constitutional Thought in United States History}

Conservative political thought in the United States is largely based on a compact federalist interpretation of American constitutionalism. The compact federalist interpretation holds that the nation is constituted of communities (states) that enter into a constitutional compact in order to maximize their common political objectives such as security against external threat. In the compact federalist view, the state and local governments are primary in the division of powers between the national government and state governments. National federalism, in contrast, holds that the national government is primary and that the nation is constituted of individuals who come together as individuals (rather than citizens of the states) to produce the nation. Major periods of domestic crises in United States history including the ratification of the Constitution, the Civil War, the New Deal, and the Civil Rights Movement were marked by the question of whether the state governments or the national government should be primary in the division of powers. While the national federalist view has triumphed in every period of domestic crisis in the United States, the compact federalist view has continued to surface throughout the nation's history and is prominent in American political discourse today.

One of the earliest expressions of the compact idea in United States history was made by Dr. John Witherspoon, a New Jersey delegate to the Continental Congress who argued before the assembly that the colonies should be considered individuals and that the Congress should be viewed as a collection of colonies. According to Ford's record, Witherspoon argued that

[The colonies] are now collected as individuals making a bargain with each other, and of course had a right to vote as individuals... That nothing relating to individuals could ever come before Congress; nothing but what would respect the colonies. He distinguished between an incorporating and a federal union... He expressed his hopes that in the present enlightened state of men's minds we might expect a lasting confederacy if it was founded on fair principles (Ford, Hunt, Fitzpatrick, \& Hill, 1907: pp. 1103-1104).

There is little doubt but that the constitutional vision embodied in Witherspoon's speech was embraced by a majority of the colonial delegates in writing the nation's first constitution, the Articles of Confederation. Designed to protect the sovereignty and independence of the states, the Articles of Confederation was primarily authored by and for the states and to the extent a national community was created by the Articles it was one of limited political and psychological significance. The Federalist's call for a new constitution signified not only the political desire to consolidate the states through a uniform system of laws, currency, and infrastructure to support economic expansion but also an accompanying desire to instill in the people a sense of national unity 
and allegiance that would lend psychological support to these new national objectives.

The ground upon which the Anti-Federalists united against the Federalists in opposition to the proposed Constitution was its consolidation of the states and the potential such consolidation held for the destruction of the states. Patrick Henry of Virginia, who almost single handedly carried the opposition argument for the first week of the Philadelphia Convention, used his forensic skill and common manner to rally the Anti-Federalists against consolidation (Storing, 1981: p. 207).

The fate of... America may depend on this: Have they said, we the States? Have they made a proposal of compact between the States? If they had, this would be a confederation: It is otherwise most clearly a consolidated government. The question turns... on that poor little thing-the expression We, the people, instead of the States of America (Storing, 1981: p. 212).

Henry's emphasis on the practical reasons for rejecting the new Constitution-to prevent consolidation and the destruction of the states-was accompanied by theoretical arguments for rejecting the document. Luther Martin of Maryland emerged at the Convention as the chief spokesperson for Anti-Federalist constitutional theory. Martin argued that "the people of the continent" were not in a "state of nature" as the proposed Constitution assumed; rather, they had escaped the state of nature by entering into a constitutional compact that had given birth to the respective State governments. These government-creating compacts not only pre-existed the compact under immediate consideration (the United States Constitution) but were still operative. The national Constitution was therefore to be viewed as a creature of the states rather than of individuals independent of their states (Storing, 1981: pp. 19-82). Based largely on the proposed Constitution's failure to embrace the compact theory of government, Martin and other Anti-Federalists attending the Convention refused to sign the document (Storing, 1981: pp. 3-83). The objectors, of course, were in the minority and the Constitution was adopted by the Philadelphia Convention in 1788 by a vote of 63-1l (Storing, 1985: pp. 255-256).

Upon final ratification of the Constitution in 1789, the substance of constitutional discussion in the United States shifted from a normative discussion of what a constitution and constitution making should entail to a descriptive discussion of what the Constitution and constitutional interpretation did entail. The shift is best represented by an extraordinary debate that ensued following the Supreme Court's decision in McCulloch v. Maryland (1819). In McCulloch, Chief Justice John Marshall combined the Necessary and Proper Clause of Article I and the Supremacy Clause of Article VI to produce a doctrine of implied powers that substantially increased the powers of the national government beyond those specifically enumerated in the Constitution. Since the Tenth Amendment reserves to the states those powers "not delegated" to the national government, the McCulloch decision, by increasing the powers of the national government beyond those specifically enumerated, necessarily limited the powers of the states. The decision outraged states' rights advocates who viewed Marshall's implied powers doctrine as a blatant and illegitimate encroachment on the powers of the states. The Richmond Enquirer, the "preeminent keeper of the states' rights flame", almost immediately began running a series of published attacks on the decision (Gunther, 1969: p. 1). The following excerpts summarize the compact federalist premise of the attacks.

The constitution of the United States was not adopted by the people of the United States, as one people. It was adopted by several states, in their highest sovereign character, that is, by the people of the said states, respectively; such people being competent, and they only competent, to alter the pre-existing governments operating in the said states (Hampden Essays, 1819).

The respective states [in] their sovereign capacity did delegate to the federal government its powers, and in so doing were parties to the compact. The states not only gave birth to the constitution, but its life depends upon the existence of the state governments (A. Virginian's “Amphictyon” Essays, 1819).

Such attacks on the McCulloch decision demonstrate that by 1819, constitutional discussion in the United States had ceased to center on prescriptive theories of American constitutionalism. The rhetoric of Patrick Henry and Luther Martin of what a legitimate system of government should entail had been replaced by a descriptive theory of American constitutional authority based on the premise that the Constitution had been ratified by the people of the sovereign states rather than directly by the people of the United States. More than ten years after the McCulloch decision, John C. Calhoun articulated a view of American constitutionalism that was later used by Calhoun and other conservatives in an attempt to justify the southern states' succession from the Union. Referring to the Virginia Resolutions of 1798-1799, Calhoun wrote: 
Their greatest and leading principle is, that the general Government emanated from the people of the several States, forming distinct political communities, and acting in their separate and sovereign capacity, and not from all of the people forming one aggregate political community; that the Constitution of the United states is in fact a compact, to which each State is a party... they have the right, in the last resort, to use the language of the Virginia resolutions, "to interpose for arresting the progress of the evil, and for maintaining within their respective limits, the authorities, rights and liberties appertaining to them" (Calhoun, 1831b: pp. 274-275).

First articulated by Thomas Jefferson in opposition to the Alien and Sedition Acts (1798-1799), the doctrine of interposition holds that the states have the right to "arrest the progress of evil" by interposing themselves between the central government and the people of the states when the central government acts in a way that is deemed to be in excess of its legitimate constitutional authority.

A century later, the doctrine of interposition was again invoked by southern state governors and legislators in an attempt to defy federal desegregation orders following the United States Supreme Court decision in Brown for Board of Education of Topeka, Kansas (1954). In December 1955, Mississippi Senator James Eastland proposed and the state legislature adopted and created the State Sovereignty Commission. The Commission was created to "do and perform any and all acts and things deemed necessary and proper to protect the sovereignty of the state of Mississippi and her sister states from encroachment thereon by the Federal government or any branch, department, or agency thereof' (Carter, 1959: p. 61 ).

Walter Sillers, Speaker of the Mississippi House of Representatives formally announced the Commission's intention to work through the doctrine of interposition to "save the white race from amalgamation, mongrelization, and destruction" (Carter, 1959: p. 63). Five years later, Mississippi Governor Ross R. Barnett explicitly invoked the doctrine of interposition in an unsuccessful attempt to block the national government from registering James Meredith at the University of Mississippi (Eyes on the Prize, 1987). While the doctrine of interposition has not reappeared in explicit form since the desegregation era, the compact federalist principles on which the doctrine is based has continued to receive constitutional and political expression in American political discourse.

\section{Contemporary Political Conservativism, States' Rights, and the Moral Imperative of Ronald Reagan}

The compact federalist theory embraced by conservatives during the Founding, Civil War, and Civil Rights eras is rarely made explicit in contemporary American political discourse. An exception, however, is found in the judicial writings of United States Supreme Court Associate Justice Clarence Thomas. Justice Thomas, by measure of his constitutional interpretation of the proper relationship between the national government and state governments, is clearly the most conservative member of the current Supreme Court. Thomas argues that Supreme Court case law since the New Deal "[comes] close to turning the Tenth Amendment on its head" and can "be read to reserve to the United States all powers not expressly prohibited by the Constitution" (Thomas, 1995a). Thomas clearly articulates his compact federalist view of American constitutionalism in his concurring opinion in Lopez by citing from Justice Iredell’s 1793 majority opinion in Chisholm v. Georgia (1793): "Each state in the union is sovereign as to all the powers reserved. It must necessarily be so, because the United States have no claim to any authority but such as the states have surrendered them” (Thomas, 1995a). Thomas again iterates his states' rights position in his dissenting opinion in U.S. Term Limits, Inc. v. Thornton (1995):

The ultimate source of the Constitution's authority is the consent of the people of each individual state, not the consent of the undifferentiated people of the nation as a whole... The Constitution simply does not recognize any mechanism for action by the undifferentiated people of the nation (Thomas, 1995b).

Thomas' assertion that the Constitution "does not recognize any mechanism for action by the undifferentiated people of the nation" bears striking resemblance to Calhoun's argument that "the very idea of an American people, as constituting a single community, is mere chimera” (Calhoun, 1831a: pp. 495-496).

Today, constitutional theory has largely been subsumed by politics and policymaking. Conservative presidential candidates, legislators and federal appellate judges most often assume the compact theory without directly articulating it. The assumption of compact federalist theory in practical politics was in large degree achieved through the rhetorical skills of former President Ronald Reagan. Reagan fused compact federalist theory with 
notions of moral progress and human obligation to produce a distinct brand of American conservativism that promotes both traditional conservative notions of states' rights and a new conservative vision of nationalism.

Reagan clearly expressed a compact federalist view of American constitutionalism when he stated in his First Inaugural Address: "All of us-all of us need to be reminded that the federal government did not create the states; the states created the federal government” (Erickson, 1985: p. 141). In reminding the American people that the states created the national government, Reagan sought to gain constitutional and popular support for his administration's plans to restructure the American government along states' right lines. Throughout his presidency, Reagan focused on the practical and moral implications of compact federalist theory and the importance of states' rights to the social, economic, and moral development of the nation.

Reagan's strategy for garnering support of his political agenda involved a negative rhetorical construction of the national government-a construction designed to invoke in the American people a sense of moral obligation to reduce the presence of central government in their lives. It is not insignificant that Reagan rarely used the term "national government" in his speeches; rather, his preference for the phrases "central government" and "Washington" rhetorically served to produce in the hearer a psychological differentiation between "legitimate" government-a government created by the states and extremely limited in scope and size-and "illegitimate" government-a large, intrusive, irresponsible government geographically situated far from the people. Reagan's rhetoric clearly conveyed the idea that he had assumed an illegitimate government when he took office, and that his mission as president was to replace "Washington" with a legitimate national government constituted by and for the states. Legitimate government, according to Reagan, would reflect "the constitutional balance envisioned by the Founding Fathers" and "return power and resources" to the state and local governments (Balitzer \& Bonetta, 1983: pp. 267-288). Reagan's rhetorical disassociation of himself from central government attempted to construct in the American consciousness an image of Reagan as an isolated presence among Washington’s “big government" political elites.

Reagan stated as early as 1964 that the "government invasion of public power" was "the most evil enemy mankind has known in his long climb from the swamp to the stars” (Erickson, 1985: p. 137). In addition to being a serious impediment to natural social progress, the "invasive" policies of the central government represented to Reagan an assault on the rights of American families and the prerogatives of the American people. In a 1983 speech given to the National Association of Evangelicals, Reagan stated:

Many of us in government would like to know what parents think about this intrusion in their family by government. We're going to fight in the court. The rights of parents and the rights of family take precedence over those Washington-based bureaucrats and social engineers. But the fight against parental notification [of abortion] is really only one example of many attempts to water down traditional values and even abrogate the original terms of American democracy. Freedom prospers when religion is vibrant and the rule of law under God is acknowledged (Erickson, 1985: pp. 158-159).

Reagan's negative rhetorical construction of the central government as immoral and anti-democratic is replete with references to the central government's encroachment on the powers of state and local governments. In a commencement address at the University of Notre Dame, Reagan linked the central government's assault on state power with the moral and political obligations of the students.

Federalism, with its built in checks and balances, has been distorted. Central Government has usurped powers that properly belong to local and State governments... All of this has led to the misuse of power and preemption of the prerogatives of people and their social institutions... We need you. We need your youth. We need your strength. We need your idealism to help us make right that which is wrong (Erickson, 1985: p. 137).

In the same speech, Reagan used his portrayal of George Gipp in the movie Knute Rockne-All American to link the moral obligation of students to reduce central government with their sense of loyalty to Notre Dame and to their late fellow alumnus, Rockne.

Now, today I hear very often, “Win one for the Gipper” spoken in a humorous vein... But let's look at the significance of that story. Rockne could have used Gipp's dying words to win a game any time. But eight years went by following the death of George Gipp before Rock revealed those dying words, his deathbed wish. And then he told the story at halftime to a team that was losing, and one of the only teams he had ever 
coached that was torn by dissention and jealousy and factionalism... For someone they had never known, they joined together in a common cause and attained the unattainable...

You are graduating from a great private, or, if you will independent university. Not too many years ago, such schools were relatively free from government interference. In recent years, Government has spawned regulations covering virtually every facet of our lives. The independent church-supported colleges and universities have found themselves enmeshed in that network of regulations and the costly blizzard of paperwork that Government is demanding...

I hope when you leave this campus that you will do so with a feeling of obligation to your alma mater. She will need your help and support in the years to come. If ever the great independent colleges and universities like Notre Dame give way to and are replaced by tax-supported institutions, the struggle to preserve academic freedom will have been lost (Erickson, 1985: p. 148-151).

Reagan offers the American people a means by which to escape the intrusive policies of "central government" and fulfill their moral obligation to reduce the central government's presence in their lives. By supporting Reagan and his administration's policies for a states' rights restructuring of government, the people would be working to ensure a transfer of power from Washington to the state and local governments. This transfer of power would in turn serve to restore the rights of the people and return the nation to the governing principles envisioned by the Founding Fathers. Reagan made this message clear in his Second State of the Union Address, when he informed Congress that a restoration of states' rights would assure his Administration and the Congress a place in history.

When I visited this Chamber last year... I proposed a new spirit of partnership between this Congress and this Administration and between Washington and our state and local governments... The record is clear, and I believe that history will remember this Administration as an Administration of change and remember this Congress as a Congress of destiny... Together, after fifty years of taking power away from the hands of the people in their states and local communities we have started returning power and resources to them... This Administration has faith in state and local governments and the constitutional balance envisioned by the Founding Fathers. We also believe in the integrity, decency, and sound good sense of grass roots Americans (Erickson, 1985: pp. 269-277).

Reagan's speeches together reveal three mutually informing constitutional and political assumptions: 1) that the states created the national government; 2) that the national government acts against the people when it usurps the powers of the state governments; and, 3) that reducing national government and returning power to the states would restore the rights and liberties of the American people. By rhetorically constructing a negative view of the national government and accentuating both the "evil" policies of the national government and its usurpation of powers "properly belonging" to the states, Reagan assumed for himself the role of interposer between Washington and the people of the states-a role Reagan likely envisioned would be assumed by the states once his national political agenda was sufficiently endorsed by the American people, adopted by congressional policy makers, and after he could no longer serve as chief national spokesperson of the United States.

\section{Reagan's Reconceptualization of Conservative Political Theory: National Political Identity and Education Policy}

The rhetoric used by the Reagan Administration contained not only the traditional conservative view of state and local autonomy but also a concise message about the goals that state and local governments should pursue in exercising their "newfound" independence and autonomy. In education policy, state and local school boards and particularly the parents of children attending public schools would be granted control of education because they, unlike the federal government, could be trusted to form the "right" kinds of education programs. As Reagan's Department of Education (DOE) Secretary, William Bennett stated: "Armed with good information the American people can be trusted to fix their own schools" (Bennett, 1986: p. vi).

The "good information" intended by the Reagan administration involved three major political interests: Reagan's interest in promulgating a states' rights theory of government; the business community's interest in improving education in order to produce a labor force capable of increasing the United States' position in international trade; and, a "moral education" interest in the Republican Party intent on increasing parental control of schools, amending the Constitution or changing legislation and constitutional interpretation to allow for school 
prayer, and expelling all signs of secular humanism from the public school curriculum.

Reagan's interest in transforming states' rights theory into practice was highly evident in his plans to deregulate public education at the national level and transfer the authority for education to state and local governments. When Reagan assumed the presidency in 1981, his education agenda was already well-known to the American people. His campaign had involved several promises for education reform including eliminating the DOE, reducing federal regulations and increasing state and local control of education, restoring morality in public schools, and improving the academic standards of public schools. While he was never able to win full support from Republican members of Congress for his proposals to abolish the DOE, Reagan was successful in significantly reducing federal regulations and increasing state and local control of education. Large groups of categorical grant programs were lumped into block grants during his administration, and state and local agencies became responsible for planning and administering the use of money allocated for each grant. Other administrative reforms such as improving the quality of teachers through merit pay further affected a shift in the control of education to state and local school systems (Spring, 1988: p. 59). By the end of Reagan's second term, the decentralization of education had resulted in a sizable increase in the responsibilities held by state governments. Governors and legislators across the country assumed considerable administrative control over a range of pro- grams and set out to unify in-state education policies through programs such as detailed curriculum requirements, career ladders, master teacher plans, and statewide competency tests of teachers and students (Spring, 1988: p. 72).

In addition to increasing state and local autonomy, Reagan's education plan sought to improve the academic performance of public schools. His plans were largely based on a 1983 Nation at Risk report by the National Commission on Excellence in Education. The report concluded that the poor quality of American public schools was responsible for the slow growth in the nation's economy (National Commission on Excellence in Education: 1983). Since at least the early 1980s, members of the business community had expressed concern that schools were producing a labor force inferior to that of Japan and West Germany, and Reagan's education strategy clearly reflected this concern (Spring, 1988: pp. 11, 59-61). As Joel Spring explains, the administration's blame of education for the nation's economic problems resulted in an increase in money in the 1980s directed toward "useful" knowledge that could be translated into an improved national economy. Mathematics, science, computer science, and foreign languages were therefore funded at the expense of other programs (Spring, 1988: pp. 59-61).

Reagan defined excellence in education not only in terms of knowledge that would improve the economy but also in terms of moral education. His addition of moral values to the political and economic mix of education policy was fueled by a Republican Party constituency that had provided Reagan with considerable electoral support during the 1980 and 1984 presidential elections. Under an umbrella organization called the Committee for the Survival of a Free Congress, religious organizations such as the Moral Majority, the Heritage Foundation, and Phyllis Schafly's Eagle Forum outlined religious policy objectives that came to hold a prominent place in Reagan's education agenda (Spring, 1988: p. 54). Reagan's support of policy initiatives such as a tuition tax credit to provide funding for private Christian schools, a school prayer amendment to the Constitution, the introduction of creationism to the curriculum of public schools, and the teaching of moral values in the classroom represented a clear endorsement of the education interests held by the conservative religious organizations that had supported and partially funded his bids for the presidency (Diamond, 1995: Chapters 7 and 10).

As Reagan worked to achieve greater autonomy for state and local governing bodies, Republican Senators Jesse Helms, Henry Hyde, and Orrin Hatch followed the social agenda of the Christian Right by introducing national legislation to restrict abortion and allow prayer in the nation's public schools. At the local level, Christian conservative activists campaigned for and were elected to state and local school boards and city councils (Diamond, 1995: pp. 171, 301). From these positions, conservatives challenged school prayer bans, textbook selections, the exclusion of creationism from the classroom, and other public school curricula. When these challenges failed to produce the desired results, Reagan himself stepped forth to propose a constitutional amendment to return "voluntary" prayer to public schools (Diamond, 1995: p. 235). While the social reform efforts of Reagan and his supporters were largely unsuccessful in the 1980s, the ground had been laid to further advance a national political identity based on Reagan's fusion of states’ rights, capitalism, and Christian values.

\section{The Rhetoric of Political Conservatism in the Post-Reagan Era}

The language of contemporary conservatism suggests a conception of local community that is in many respects distinct from that held by traditional conservatives. The autonomous, self-defined, sovereign local community envisioned by the Anti-Federalists (although clearly understood in terms of a homogenizing center for instilling 
civic virtue, morals, and values) came to be seen by many conservatives in the 1980s as part of a larger national community founded on family values, Christian values, and free market principles. In neither the writings of the Anti-Federalists nor those of the Civil War successionists do we find a desire to nationalize the specific beliefs or conceptions held by a local community with the exception of a general belief in compact federalism. John C. Calhoun, for example, defended the "right" of South Carolina and other southern states to determine for themselves the issue of slavery and to protect the decision it made. However, he never argued that slavery should be nationalized or that other states should be bound by the decisions of South Carolina. Contemporary conservatives, on the other hand, argue for the sovereignty and autonomy of state and local communities but simultaneously attempt to nationalize the political, economic, and moral principles that state and local policy should embrace.

Nationalized conceptions of local community were clearly expressed through the rhetoric of the "compassionate conservative” Republican presidential candidate, Governor George W. Bush. The nationalist conceptions advanced by Bush in his 2000 presidential campaign were clearly those promoted by Reagan in the 1980s; however, Reagan's rhetoric had so penetrated national consciousness by the year 2000 that a decided shift had occurred in American political discourse. An ideological shift to the right had allowed the Republican Party to gain control of both chambers of Congress in 1994, and also enable Bush to campaign on a platform that empowered state and local governments to vigorously pursue nationalized conservative conceptions of government. As Bush defined the conservative agenda in his Remarks at Bob Jones University:

We are conservatives because we believe in freedom and its possibilities, family and its duties, faith and its mercies. We believe in opportunity for all Americans: Rich and poor, black and white, young and old, born and unborn... I will work to restore standards, discipline, and decency to our public schools... I will respect and rebuild our military... I will return honor and dignity to the White House... I will cut taxes... I'm going to make the case that our conservative principles are compassionate principles. That work and responsibility are better than dependency on government. That local control, and standards, and parental choice are better for our children than the schemes of some towering, centralized bureaucracy (Bush, 2000c).

The "towering, centralized bureaucracy" Bush campaigned against was rhetorically personified in his presidential campaign opponent, Al Gore. Bush attempted throughout his campaign to duplicate the rhetorical strategy of Reagan by contrasting his states' rights approach to government with his opponent's liberal, "big central government," "Washington insider" approach. The contrast is clearly seen in a campaign speech given by Bush in Pittsburgh, Pennsylvania, twelve days before the election.

I believe education is a national priority, but a local responsibility. I want to give schools the resources and authority to chart their own path to excellence. My opponent thinks Washington knows best. I believe that when low-income children are trapped in failing schools, their parents should be trusted to make other choices. My opponent would deny them those options. I believe that seniors should have a better Medicare system... My opponent has a one-size-fits-all answer, dictated by Washington from Washington... I believe in supporting the good work of churches and charities in communities across America. My opponent calls their work the "crumbs of compassion" and looks to government instead... Vice President Gore is promoting a big build-up of big government-more spending, more programs, more of Washington talking down to us and thinking on our behalf (Bush, 2000d).

In most political environments, Bush's lack of national political experience would have been considered a detriment and Gore's extensive experience and tenure as a national officeholder an asset. But a post-Reagan, post-Lewinsky, post-impeachment political climate allowed Bush to transform the concept of experience from a positive to a negative qualification for holding the Office of the President. Bush promoted his "outsider" status in a way reminiscent of Reagan, and was able to enhance his outsider status by exploiting his Texas roots, however un-humble those roots might have been, as well as his down-home Texas persona. Bush explained the symbolic significance of his Texas heritage in his Acceptance Speech at the 2000 Republican National Convention:

[My opponent] now leads the party of Franklin Delano Roosevelt. But the only thing he has to offer is fear itself. That outlook is typical of many in Washington-always seeing the tunnel at the end of the light. But I come from a difference place, and it has made me a different leader. In Midland, Texas, where I grew up 
the town motto was "the sky is the limit" and we believed it... Tonight, in this hall, we resolve to be, not the party of repose, but the party of reform... We are now the party of ideas and innovation... The party of idealism and inclusion (Bush, 2000a).

The new conservative image of the Republican party as the party of "reform" and "innovation", an image sharply contrasting that of traditional conservativism, had been present in American political discourse and conservative thought for almost two decades. Reagan's success in shaping public opinion around the concept of states' rights theory was "assumed" rather than debated. Even President Clinton while in office recognized the states' rights tenor in American political discourse. In 1993, for example, Clinton vowed to establish a "new relationship, a new partnership" with local governments in an understanding that they should have "more flexibility to do work without so much micromanagement and regulation from the national government" (Clinton, 1993). Clinton's references to the autonomy of state and local governments were even more pronounced after the 1994 party realignment in Congress. His Goals 2000 Project, for example, relied heavily on the states to design, implement, and stand accountable for the results of federal investments in education (Lewis, 1995). As Clinton's Education Secretary Richard W. Riley stated in his "State of American Education Address" in February, 1997, Clinton's education plan was "national in scope yet local in action because that's the American way" (Riley, 1997).

While Reagan's rhetoric stressed the importance of adopting a states' rights theory of government to enable the nation to achieve economic and moral success, Bush's rhetoric assumed theory and proceeded toward a practical policy agenda for realizing economic success within a states’ rights framework. Bush blended states' rights and capitalism into a single policy statement that proved to be the centerpiece of his campaign: The privatization of state and local services. Bush rhetorically constructed privatization as the inevitable result of a technological age.

Technology and information have created a remarkable age where time and distance have shrunk to almost nothing. The effect of all this is clear: more choices, more information, and more power for the citizens and local communities. This new culture has extended its reach into some levels of government, which are transforming the way they do business (Bush, 2000b).

Bush continued his speech by outlining specific examples of cities and states that had privatized public services particularly in the areas of education, sanitation, and airport services. Competitive bidding over the Internet had enhanced privatization efforts and improved privatization processes. But Washington, Bush argued, had failed to see the inevitability of states' rights in a technological age and the way in which both privatization and technology empowered state and local communities. The "reformist" component of his campaign was to bring Washington into the $21^{\text {st }}$ century by decentralizing central government and privatizing local governmental services.

Across America, people are learning about this trend of reform. Yet it appears largely to have escaped the notice of the federal government. Today, when Americans look to Washington, they see a government slow to respond, slow to reform, and ignoring all the changes going on around it. At times the government is irrational, running things without any standard of what is necessary, or even what was intended (Bush, 2000b).

The addition of the phrase "or even what was intended" to this passage appears out of place when considered outside the context of post-Reagan conservative political discourse. Reagan's fusion of moral obligation with compact federalist theory rhetorically served to ascribe a sense of inevitability to a states' rights form of government, and inevitability was christened by invoking the Founders' intent. According to compact federalist theory, "what was intended" by the Founding Fathers was a government in which state and local governments were empowered to serve the people. Thus, in Bush's rhetorical view, privatization fulfills the intent of the Founding Fathers because it propels the nation toward an inevitable return to states' rights government-a return paved by free market competition and expedited by technological progress.

Bush's "compassionate conservative" theme provided him the base from which to launch a covert moral attack against Gore for his affiliation with the "scandal-ridden" Clinton administration. Through campaign rhetoric, Bush was able to give the appearance of practicing the art of morality rather than preaching it. Invoking his own sense of Christian morals and decency, Bush rhetorically bestowed "forgiveness" upon Gore for his 
trespass of serving a scandalous, broken, tarnished administration.

I believe in tolerance, not in spite of my faith but because of it. I believe in God who calls us, not to judge our neighbors, but to love them. I believe in grace, because I have seen it; in peace because I have felt it; in forgiveness because I have needed it. I believe true leadership is a process of addition, not an act of division. I will not attack a part of this country, because I want to lead the whole of it... My fellow citizens, we can begin again. After all of the shouting, and all of the scandal. After all of the bitterness and broken faith. We can begin again... Our country is ready for high standards and new leaders, and it won't be long now. An era of tarnished ideals is giving way to a responsibility era, and it won't be long now... I know the presidency is an office that turns pride into prayer... And I believe America is ready for a new beginning (Bush, 2000a).

Bush made his "new beginning" clear to the American people shortly after he assumed office on January 21, 2001. A little over a month into his presidency, Bush outlined a "honeymoon" agenda that included vouchers to public school students, federal aid to faith-based social programs, a tax cut plan to redeem his father's broken promise, and a new "beginning of the end" of the Persian Gulf War. President Bush's pledge to inject local government services government services with capitalistic competition through vouchers and privatization efforts represented the traditional conservative desire to return power to local governing bodies. However, the idea of capitalistic competition in the sector of public goods and services served to blur the distinction between what is or should be considered a public societal good and what is or should be considered a private individual commodity. "New conservative" attempts to nationalize certain principles of free market and morality further eroded the public/private distinction, as evidenced by priority spending proposals for publicly funded vouchers and federal aid to faith-based social programs.

\section{Conclusion}

American political discourse at the beginning of the $21^{\text {st }}$ century reflected only a peripheral understanding of how political conceptions of the public and private might significantly impact all areas of public policy in the coming years. Furthermore, the compact federalist ideology of Reagan had so penetrated American political discourse that the historical question of whether the national government or the state governments should be considered primary in the division of government powers rarely receives expression. Rather, the question that guided political discourse at the beginning of the new millennium concerned the degree to which the national government should legislatively and economically support state and local initiatives that began under Reagan and were reintroduced and pragmatically pursued by the Bush administration. Former President Reagan's rhetorical fusion of states' rights theory, capitalism, and Christian morality served to shift the ideological center of American political discourse to the right, thus paving the way for a 21 ” century conservatism that is both states' rights and nationalist.

\section{References}

A. Virginian’s “Amphictyon” Essays (1819). In G. Gunther (Ed.), John Marshall’s Defense of McCulloch v. Maryland (pp. 52-77). Stanford, CA: Stanford University.

Balitzer, A. A., \& Bonetto, G. M. (Eds.). (1983). A Time of Choosing: The Speeches of Ronald Reagan, 1961-1982. Chicago, IL: Regnery Gateway Press.

Bennett, W. (1986). What Works: Research about Teaching and Learning. Washington DC: U.S. Government Printing Office.

Brown for Board of Education of Topeka, Kansas (1954). 347 U.S. 483.

Bush, G. W. (2000a). Acceptance Speech. Delivered Philadelphia, PA, August 3, 2000.

Bush, G. W. (2000b). Getting Results from Government. Delivered Philadelphia, PA, June 9, 2000.

Bush, G. W. (2000c). Remarks at Bob Jones University. Greenville, SC. February 2, 2000.

Bush, G. W. (2000d). Responsible Leadership. Delivered Pittsburgh, PA, October 26, 2000.

Calhoun, J. C. (1831a). Cited in R. L. Meriwether (1959). The Papers of John C. Calhoun (pp. 495-496). Columbia: University of South Carolina Press.

Calhoun, J. C. (1831b). The Fort Hill Address. In C. N. Wilson (Ed.), The Essential Calhoun: Selections from Writings, Speeches, and Letters. New Brunswick: Transaction Publishers. 
Carter, H. (1959). The South Strikes Back. New York: Doubleday.

Clinton, W. (1993). Teleconference Remarks. In Weekly Compilation of Presidential Documents (Vol. 29, pp. 1150-1153). Washington DC: Office of the Federal Register, National Archives and Records Administration.

Diamond, S. (1995). Road to Dominion: Right-Wing Movements and Political Power in the United States. New York: The Guilford Press.

Erickson, P. D. (1985). Reagan Speaks: The Making of an American Myth. New York: New York University Press.

Eyes on the Prize (PBS Series 1) (1987). America's Civil Rights Years, 1954-1965, Series 1. Arlington, VA: PBS.

Ford, W. C., Hunt, G., Fitzpatrick, J. C., \& Hill, R. R. (Eds.) (1907). Journals of the Continental Congress 1774-1789. Washington DC: Library of Congress.

Gunther, G. (Ed.) (1969). John Marshall's Defense of McCulloch v. Maryland. Stanford, CA: Stanford University Press.

Hampden Essays (1819). In G. Gunther. (Ed.), John Marshall's defense of McCulloch v. Maryland. Stanford, CA: Stanford University Press.

National Commission on Excellence in Education (1983). A Nation at Risk: The Imperative for Education Reform (pp. 1-48). Washington DC: U. S. Department of Education.

Riley, R. (1997). State of American Education Address. In P. Applebome (Ed.), New Call for Support of Clinton on Schools (p. A17). New York Times. February 19, 1997.

Spring, J. (1988). Conflict of Interests: The Politics of American Education. New York: Longman Press.

Storing, H. J. (1981). The Complete Anti-Federalist (Vol. 2). Chicago, IL: University of Chicago Press.

Thomas, C. (1995a). Concurring Opinion. U. S. v Lopez, 514 U.S. 549.

Thomas, C. (1995b). Dissenting Opinion. U. S. Term Limits, Inc. v. Thornton, 514 U.S. 779. 